\title{
Measurements of DC Resistivity of Insulating Oils
}

DOI:

10.1109/ICHVE.2016.7800895

\section{Document Version}

Accepted author manuscript

Link to publication record in Manchester Research Explorer

\section{Citation for published version (APA):}

Mu, Z., Wang, Z., \& Liu, Q. (2017). Measurements of DC Resistivity of Insulating Oils. In International Conference on High Voltage Engineering and Application (IEEE Transactions on Dielectrics and Electrical Insulation). https://doi.org/10.1109/ICHVE.2016.7800895

\section{Published in:}

International Conference on High Voltage Engineering and Application

\section{Citing this paper}

Please note that where the full-text provided on Manchester Research Explorer is the Author Accepted Manuscript or Proof version this may differ from the final Published version. If citing, it is advised that you check and use the publisher's definitive version.

\section{General rights}

Copyright and moral rights for the publications made accessible in the Research Explorer are retained by the authors and/or other copyright owners and it is a condition of accessing publications that users recognise and abide by the legal requirements associated with these rights.

\section{Takedown policy}

If you believe that this document breaches copyright please refer to the University of Manchester's Takedown Procedures [http://man.ac.uk/04Y6Bo] or contact uml.scholarlycommunications@manchester.ac.uk providing relevant details, so we can investigate your claim.

\section{OPEN ACCESS}




\title{
Measurements of DC Resistivity of Insulating Oils
}

\author{
Z. Mu, Z.D. Wang*, and Q. Liu \\ School of Electrical and Electronic Engineering \\ The University of Manchester \\ Manchester, M13 9PL, United Kingdom \\ *zhongdong.wang@manchester.ac.uk
}

\begin{abstract}
Insulating oils are widely used in power transformers. The oil insulation degrades under multiple stresses during the transformer operation, which affects the insulation integrity and consequently could cause transformer failures. DC resistivity is one of the dielectric parameters of insulating oil for assessing transformer insulation conditions. This paper presents results of DC resistivity measurements of oil samples including a mineral oil and a synthetic ester in fresh and thermally-aged conditions as well as two in-service aged oil samples in a cylindrical test cell under temperature range of $20^{\circ} \mathrm{C}$ to $100^{\circ} \mathrm{C}$. Two standards of DC resistivity measurement namely IEC 60247 and ASTM D 1169 were applied. For mineral oil, the results of ASTM D 1169 are higher than those of IEC 60247 which is caused by polarity dependence of DC resistivity. For the other samples, the results are the same for both standards. Further investigation on polarity dependence shows that it might be caused by different ion injection strength of the inner and outer electrodes.
\end{abstract}

Keywords - Transformers, condition monitoring, insulating oil, resistivity, polarity dependence.

\section{INTRODUCTION}

Transformers are one of the most important components of power systems. Condition monitoring of transformers helps determine the maintenance and replacement decisions of transformers [1]. The insulating oil in transformers plays the roles of coolant and insulation [2]. DC resistivity of the oil is one of key parameters to assess the transformer insulation condition, based on the fact that the DC resistivity is sensitive to the oil degradation [3]. Generally speaking, there are three standards for measuring the DC resistivity of insulating oil.

The first standard is IEC 60247 which provides the method for measuring steady-state DC resistivity according to the voltage-current ratio means. The electrification time and field strength proposed are 60 seconds and $250 \mathrm{~V} / \mathrm{mm}$, respectively [4].

The second standard is ASTM D 1169 which also provides the method for measuring steady-state DC resistivity according to the voltage-current ratio means. Compared with IEC 60247 , both positive and negative voltage polarities are required in ASTM D 1169 and the resistivity value is the average of results obtained under both polarities. The possible reason to use both polarities is to eliminate effect caused by dissimilar metal or temperature contacts in the liquid. The proposed electrification time is 60 seconds and the field strength ranges from $200 \mathrm{~V} / \mathrm{mm}$ to $1200 \mathrm{~V} / \mathrm{mm}$ are specified [5].

The third standard is IEC 61620 which is basically for measuring dissipation factor of the insulating liquids based on the Equation (1).

$$
\operatorname{Tan} \delta=1 / \mathrm{R} \omega \mathrm{C}
$$

Although this is a standard to determine the dissipation factor, a method to determine the initial DC resistivity which is based on Equation (1) is also proposed, according to voltage-current ratio and square wave means. The square wave is applied to the sample and the value is sampled at the flat level of current at each half period. The voltage range of $10-$ $100 \mathrm{~V}$ is proposed and frequency range of $0.1-1 \mathrm{~Hz}$ is adopted [6].

In this paper, standards of IEC 60247 and ASTM D 1169 were applied to six individual oil samples including fresh and thermally aged mineral oil, fresh and thermally aged synthetic ester as well as two in-service aged transformer oil samples to determine the DC resistivity. The comparisons between IEC 60247 and ASTM D 1169 standards are discussed and the dependence of DC resistivity on the polarity is investigated in this paper.

\section{EXPERIMENTAL SETUP AND SAMPLES}

\section{A. Test setup}

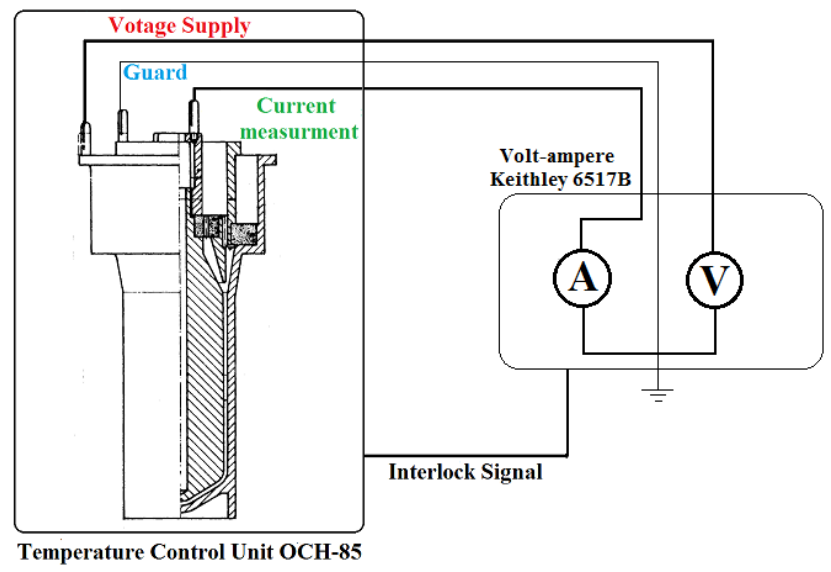

Figure 1: Sketch of Measuring Circuit (Test Cell adopted from [4])

The test-setup is shown in Figure 1. A cylindrical shape test cell with three terminals was used to hold the oil samples. The gap distance between the electrodes is set to $2 \mathrm{~mm}$ and liquid volume is $70 \mathrm{ml}$. The temperature of the test cell is 
controlled by a heater $\mathrm{OCH}-85$ with the range from $20^{\circ} \mathrm{C}$ to $110^{\circ} \mathrm{C}$. An electrometer Keithley $6517 \mathrm{~B}$ serves as the DC resistivity measuring device. There is an interlock connection between the heater and the measuring device for safety control purpose.

\section{B. Samples under investigation}

There are six oil samples measured in this paper as listed in Table 1. The Sample1 and Sample 5 are fresh mineral oil and synthetic ester manufactured by Nynas and M\&I Material, respectively. Before measurements, the fresh samples were filtered, dehydrated and degassed. The Sample 2 and Sample 6 are the thermally-aged oils which were aged under $134^{\circ} \mathrm{C}$ for 42 days. The Sample 3 and Sample 4 are the mineral oil taken from in-service transformers. Sample 3 was taken from a 53year-old $180 \mathrm{MVA} 275 / 132 \mathrm{kV}$ transformer with the acidity of $0.113 \mathrm{mg} * \mathrm{KOH} / \mathrm{g}$ while Sample 4 was taken from a 57 -yearold $120 \mathrm{MVA} 275 / 132 \mathrm{kV}$ transformer with the acidity of $0.290 \mathrm{mg} * \mathrm{KOH} / \mathrm{g}$.

Table 1: Details of Six Oil Samples Investigated

\begin{tabular}{|c|c|c|c|c|}
\hline $\begin{array}{c}\text { Sample } \\
\text { ID }\end{array}$ & Oil Type & Description & $\begin{array}{c}\text { Color } \\
\text { /Appearance }\end{array}$ & Acidity $(m g * \mathrm{KOH} / g)$ \\
\hline 1 & $\begin{array}{l}\text { Mineral } \\
\text { Oil }\end{array}$ & $\begin{array}{c}\text { Fresh } \\
\text { Gemini X }\end{array}$ & $\begin{array}{c}\text { Colorless } \\
\text { /Transparent }\end{array}$ & 0.006 \\
\hline 2 & $\begin{array}{l}\text { Mineral } \\
\text { Oil }\end{array}$ & $\begin{array}{l}\text { Thermally } \\
\text { aged } \\
\text { Gemini X }\end{array}$ & $\begin{array}{l}\text { Light Brown/ } \\
\text { Semi- } \\
\text { transparent }\end{array}$ & 0.159 \\
\hline 3 & $\begin{array}{c}\text { Mineral } \\
\text { Oil }\end{array}$ & $\begin{array}{c}\text { In-service } \\
\text { aged Mineral } \\
\text { Oil }\end{array}$ & $\begin{array}{l}\text { Dark Brown } \\
\text { Transparent }\end{array}$ & 0.113 \\
\hline 4 & $\begin{array}{c}\text { Mineral } \\
\text { Oil }\end{array}$ & $\begin{array}{c}\text { In-service } \\
\text { aged Mineral } \\
\text { Oil }\end{array}$ & $\begin{array}{l}\text { Dark Brown } \\
\text { /Transparent }\end{array}$ & 0.290 \\
\hline 5 & $\begin{array}{l}\text { Synthetic } \\
\text { Ester }\end{array}$ & $\begin{array}{c}\text { Fresh } \\
\text { Midel } 7131\end{array}$ & $\begin{array}{l}\text { Light yellow/ } \\
\text { Transparent }\end{array}$ & 0.027 \\
\hline 6 & $\begin{array}{l}\text { Synthetic } \\
\text { Ester }\end{array}$ & $\begin{array}{c}\text { Thermally } \\
\text { aged } \\
\text { Middle } 7131\end{array}$ & $\begin{array}{c}\text { Yellow } \\
\text { /Transparent }\end{array}$ & 0.655 \\
\hline
\end{tabular}

\section{DC RESISTIVITY MEARUREMENTS OF OIL SAMPLES Using TWO STANDARDS}

For the DC resistivity in this section, Standards of IEC 60247 and ASTM D 1169 were applied. Field strength of 250 $\mathrm{V} / \mathrm{mm}$ and electrification time of 60 seconds were utilized for both standards. For each samples, DC resistivity measurements were performed with temperature ranges from $20^{\circ} \mathrm{C}$ to $100^{\circ} \mathrm{C}$ at step of $10^{\circ} \mathrm{C}$. Each result reported is the average of four measurements.

Figure 2 shows DC resistivity values of mineral oils under fresh and thermally aged conditions (i.e. Sample 1 and 2) by applying two standards. The Arrhenius relationship is applicable as the plots indicate straight lines in log-y-axis plot. As shown in Figure 2, the DC resistivity for the same mineral oil sample at the same test temperature is always higher by using ASTM D 1169 (measurements under both polarities), compared to that by using IEC 60247 (measurements under only positive polarity). This is caused by that resistivity measured under negative polarity is higher than that under positive polarity leading to higher value of ASTM D 1169, which will be discussed in Section IV. Besides, as thermal aging leads to acidity increasing from 0.006 to $0.159 \mathrm{KOH} / \mathrm{mg}$, decrease of two orders of magnitude in DC resistivity can be observed in Figure 2. Figure 3 shows the results for two inservice aged mineral oil samples (i.e. Sample 3 and Sample 4). Arrhenius relationship is also observed. It is noticed that, for the samples taken from in-serve transformers, measurements using the two standards (i.e. IEC 61620 and ASTM D 1169) result in similar values at all test temperatures. Moreover, it is shown that the DC resistivity values of Sample 3 and Sample 4 decrease to the order of $10^{12}$ after more than fifty-year inservice aging. Although, the acidity of sample 4 is higher than that of sample 3, the difference in DC resistivity is minor.

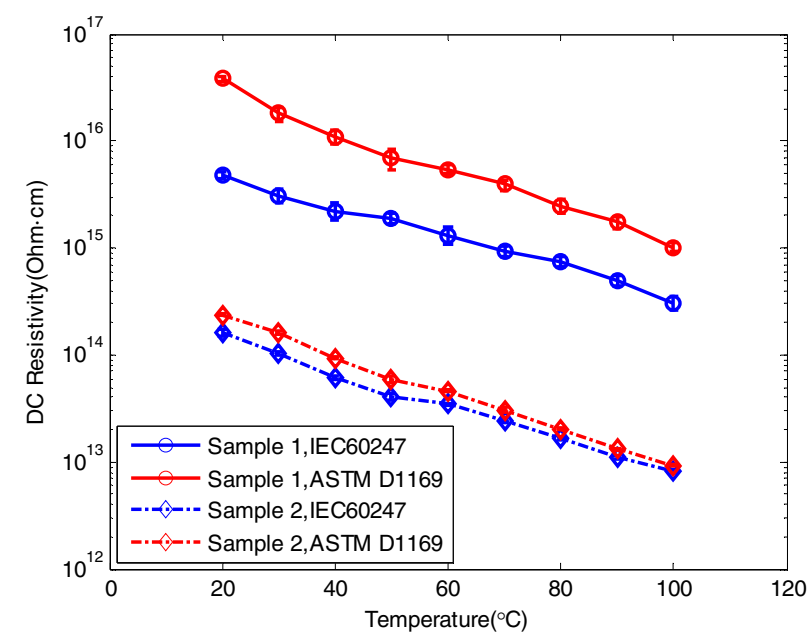

Figure 2: DC Resistivity of Sample 1 (Fresh Mineral Oil) and Sample 2 (Thermally-aged Mineral Oil)

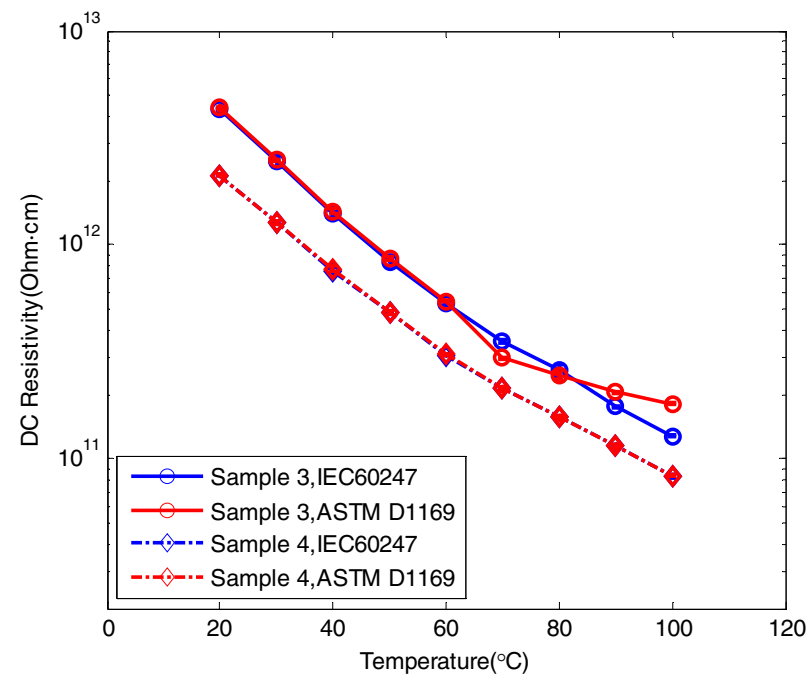

Figure 3: DC Resistivity of In-service Aged Mineral oil samples 3 and 4

Figure 4 shows the results for the synthetic ester MIDEL 7131 in fresh and thermally aged conditions (i.e. Sample No.5 and No.6). The Arrhenius relationship between the resistivity and temperature is also confirmed to these two samples and no obvious difference between results from IEC 60247 and ASTM D 1169 is indicated for both samples. It is noted that, compared to Figure 2, the synthetic ester behaves more conductive as the DC resistivity is almost around 3 orders of magnitude lower than that of the mineral oil for fresh samples. Although the thermal aging of the synthetic ester causes the acidity increasing to $0.655 \mathrm{mg} * \mathrm{KOH} / \mathrm{g}$, the decrease in $\mathrm{DC}$ 
resistivity is within one order of magnitude as shown in Figure 4.

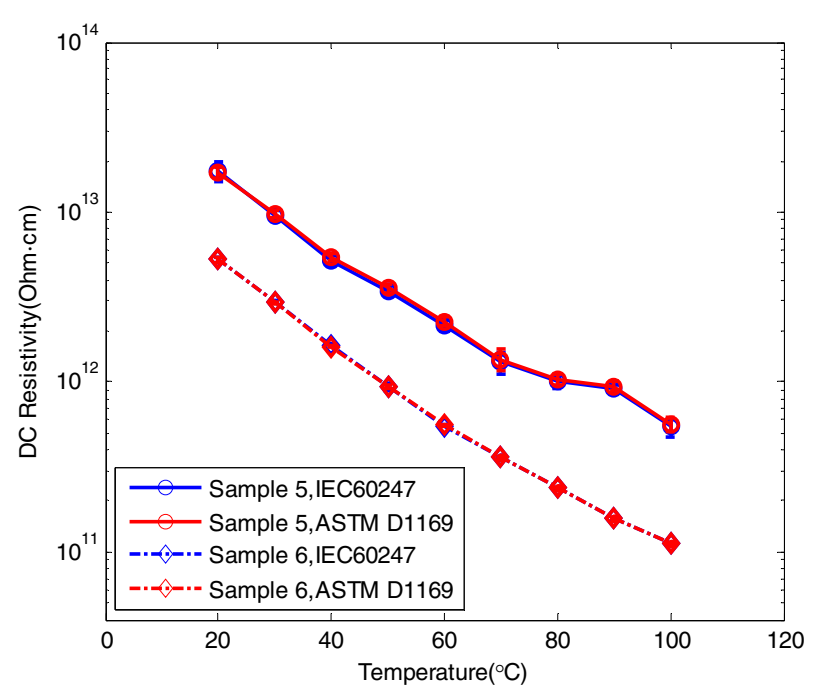

Figure 4: DC Resistivity of oil samples 5 (Fresh Synthesis Ester) and Sample 6 (Thermally-aged Synthesis Ester)

\section{Polarity DePENDENCE InVESTIGATION}

To further investigate the dependence of DC resistivity on the polarity, the fresh mineral oil and fresh synthetic ester were chosen as the former one indicated polarity dependence while the latter one did not. The investigations include measurements of DC resistivity under a wide range of field strengths (i.e. $10 \mathrm{~V} / \mathrm{mm}, 25 \mathrm{~V} / \mathrm{mm}, 50 \mathrm{~V} / \mathrm{mm}, 125 \mathrm{~V} / \mathrm{mm}, 250$ $\mathrm{V} / \mathrm{mm}, 375 \mathrm{~V} / \mathrm{mm}$ and $500 \mathrm{~V} / \mathrm{mm}$ ) at the temperature of $90^{\circ} \mathrm{C}$. For the definition of electrification time, both IEC 61620 and ASTM D 1169 propose one minute, which might not reach the steady state. Therefore besides the measurements taken at one minute, one-hour resistivity values were also investigated. It is noted that each reported result of DC resistivity is the average of two measurements.

Figure 5 plots the one-minute and one-hour DC resistivity measurements under both polarities for the fresh mineral oil. As shown in Figure 5, in terms of one-minute result, under the field strength up to $50 \mathrm{~V} / \mathrm{mm}$, the DC resistivity is stable indicating Ohmic conducting regime. When the field strength is higher than $50 \mathrm{~V} / \mathrm{mm}$, DC resistivity increases with the field strength indicating saturation conducting regime [7]. For onehour results, the Ohmic conducting regime is observed at field strength lower than $25 \mathrm{~V} / \mathrm{mm}$, above which the saturation conducting regime is shown. The ratio of negative result over positive one is plotted in Figure 6, it can be found that, dependence caused by the polarity is field-dependent as the ratio increases with the rise of field strength. For both oneminute and one-hour results, the ratio keeps at around one (i.e. week polarity dependence) in Ohmic conducting regime, whereas, the ratio gradually increases when the conducting regime becomes saturation. It can be also found that the polarity dependence is stronger for one-hour electrification than that of one-minute as the ratio increases gradually with field strength from approximately 1 to 1.5 at one-minute electrification time and to 2 at one-hour electrification time.

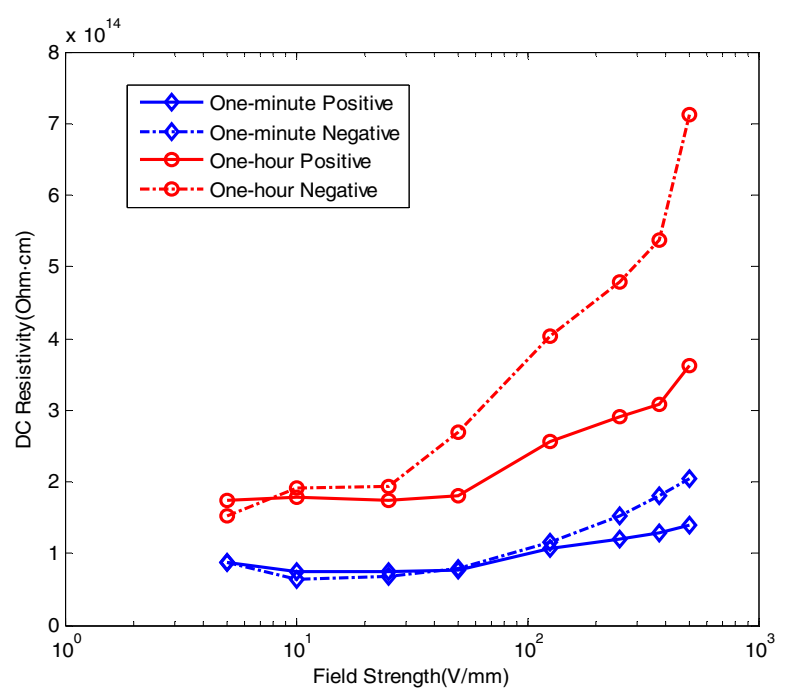

Figure 5: DC Resistivity Values at one-minute and one-hour electrification time for the mineral oil Gemini X, fresh condition, positive and negative polarities.

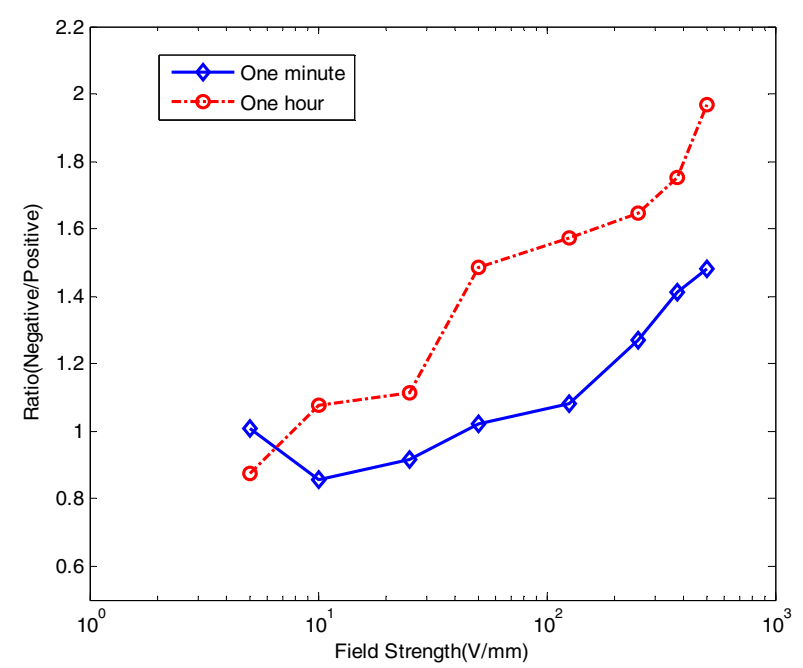

Figure 6: Ratio of negative resistivity /positive resistivity for the mineral oil

Figure 7 plots the one-minute and one-hour DC resistivity measurements under both polarities for the fresh synthetic ester. As shown in Figure 7, within the range from $5 \mathrm{~V} / \mathrm{mm}$ to $500 \mathrm{~V} / \mathrm{mm}$, the conduction of the fresh synthetic ester behaves quasi-Ohmic as only slight increase of resistivity along the rise of field strength is observed. This is very different from the mineral oil. DC resistivity for mineral oil under $500 \mathrm{~V} / \mathrm{mm}$ is up to 4 times larger than that under $5 \mathrm{~V} / \mathrm{mm}$ and this indicates that Ohmic conducting region for fresh MIDEL 7131 is much larger than that of fresh Gemini X. By comparing Figure 5 and Figure 7, one-hour results are closer to one-minute results for the synthetic ester than for the mineral oil, which shows quicker polarization for MIDEL 7131 as the current measured is the summation of steady-state DC current and polarization current. As shown in Figure 8, the ratio is around 1 in all test conditions, which indicates there is no polarity dependence of DC resistivity for the synthetic ester. 


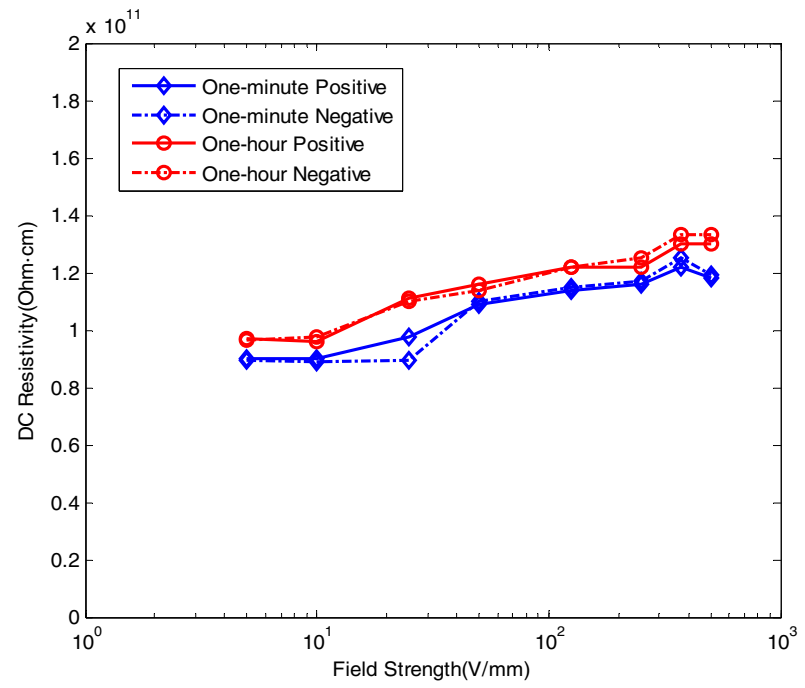

Figure 7: One-minute and One-hour DC Resistivity Values of the synthetic ester Midel 7131, fresh condition, both positive and negative polarities

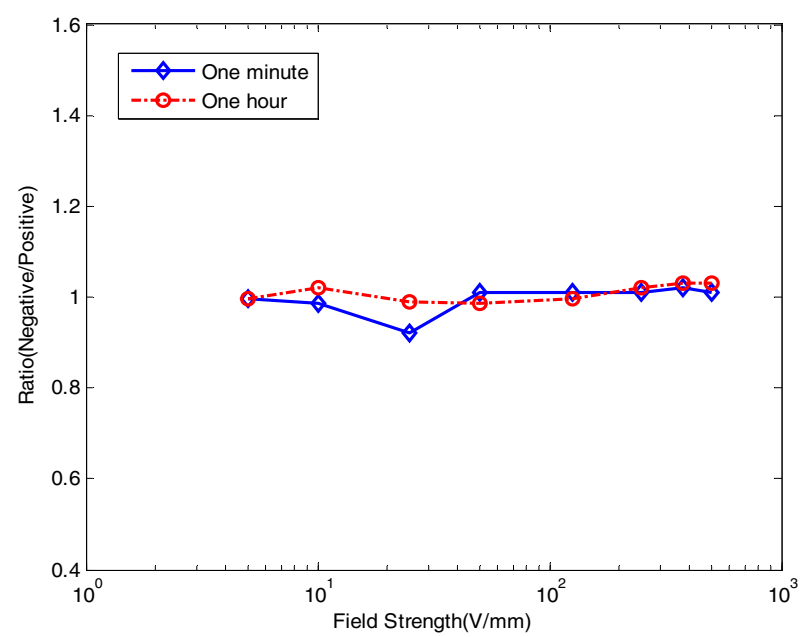

Figure 8: Ratio of negative resistivity /positive resistivity for the synthetic oil

The charge carriers in dielectric liquids under low field strength are mainly ions, and ionic conduction of dielectric liquids is either bulk-limited or interface-limited [7]. In terms of bulk-limited mechanism, dissociation of the ion pairs contributes to the most charge carriers, whereas for interfacelimited conduction, the unipolar ion injection at the metal electrode is the main source of charge. With regard to unipolar injection, cathode usually injects charge carriers for dielectric liquids [8]. It is reported that in saturation conducting regime of dielectric liquids, the source of the charge carrier are mainly from the injection, whereas in Ohmic regime, the dissociation of the ion pair plays as the main charge source [9]. Since the test cell used for the measurement is of coaxial cylindrical type, the field distribution is not even in such geometry so that the adjacency to inner electrode has higher strength than the outer electrode. As the polarity effect is observed in the saturation regime, field-dependent ion injection is dominated. For the test cell shown in Figure 1, the injecting electrode is the inner one when applying positive polarity or the outer one when applying negative polarity. Under positive polarity, the current would be higher as ion injection is higher at the inner electrode that with higher injection strength, whereas under negative polarity, the current would be lower as ion injection is lower at the outer electrode that with lower injection strength [10].

\section{CONCLUSION}

In this paper, two standards (i.e. IEC 60247 and ASTM D 1169) were applied to measure the DC resistivity of oil samples including fresh and thermally aged mineral oils, fresh and thermally ester liquids and two in-service aged oil samples. It was found that for fresh and thermally-aged mineral oils, results from ASTM D 1169 are always higher than those of IEC 60247, which is caused by polarity dependence of DC resistivity. Little difference between the results from these two standards was observed for other samples.

The investigation on polarity dependence showed that, for the fresh mineral oil, the polarity dependence appears when the conducting is in saturation regime and the dependence gets stronger at higher field strength and longer electrification time. For fresh synthetic ester, the conducting was found to be Ohmic among testing field strength from 5 to $500 \mathrm{~V} / \mathrm{mm}$ and no polarity dependence was observed. .

\section{REFERENCES}

[1] Feng, D., Wang, Z., \& Jarman, P, “Evaluation of Power Transformers' Effective Hot-Spot Factors by Thermal Modeling of Scrapped Units, " IEEE Trans. on Power Del., Vol 29.5, pp. 2077-2085, Oct 2014.

[2] Zhou, Y., Hao, M., Chen, G., Wilson, G., \& Jarman, P, "Quantitative study of electric conduction in mineral oil by time domain and frequency domain measurement," IEEE Trans. on Dielect. and Electr. Insul, Vol 22.5, pp. 2601-2610, Oct 2015.

[3] IEC Standard, Mineral insulating oils in electrical equipment Supervision and maintenance guidance, BS EN 60422:2013.

[4] IEC Standard, Insulating liquids - Measurement of relative permittivity, dielectric dissipation factor ( $\tan \&$ ) and d.c. resistivity, BS EN 60247:2004

[5] ASTM Standard, Standard test method for specific resistance (Resistivity) of Electrical Insulating Liquids, ASTM D 1169 - 11.

[6] IEC Standard, Insulating liquids - determination of the dielectric dissipation factor by Measurement of the Conductance and Capacitance -test method, BS EN 61620:2012

[7] Sha, Y., Zhou, Y., Nie, D., Wu, Z., \& Deng, J, "A study on electric conduction of transformer oil," IEEE Trans. on Dielect. Electr. Insul, Vol 21.3, pp.1061-1069, Jun 2014.

[8] Alj, A., Denat, A., Gosse, J. P., Gosse, B., \& Nakamura, I, “ Creation of charge carriers in nonpolar liquids," IEEE Trans.s on Electr. Insul, Vol 2, pp. 221-231.

[9] Pontiga, F, and Antonio, C, "Electrical conduction of electrolyte solutions in nonpolar liquids, "IEEE Trans. Ind. Appl. Vol 32.4 pp.816824, Jul 1996, Apr 1985.

[10] Denat, A., B. Gosse, and J. P. Gosse, "Ion injections in hydrocarbons," Journal of Electrostatics, Vol 7, pp.205-225, Aug 1979. 